\title{
Ectodermal dysplasia-related disorders of the respiratory tract
}

\author{
Timothy J Fete \\ From 5th International Conference on Ectodermal Dysplasia (ED2012) \\ Erlangen, Germany. 1-3 June 2012
}

Ectodermal dysplasia syndromes are frequently associated with manifestations of disease in the respiratory tract. Commonly, patients present with signs and symptoms of sinusitis, otitis media with effusion, bronchitis or pneumonia. The etiologic bases for these disorders are multi-factorial, including abnormal mucous production, anatomical variations, atopy and immune function abnormalities. This presentation reviews the current literature on the clinical manifestations and potential underlying causes for the noted increase in morbidity due to respiratory disease in the ectodermal dyplasia syndromes.

Published: 25 May 2012

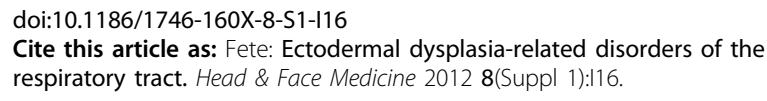

Submit your next manuscript to BioMed Central and take full advantage of:

- Convenient online submission

- Thorough peer review

- No space constraints or color figure charges

- Immediate publication on acceptance

- Inclusion in PubMed, CAS, Scopus and Google Scholar

- Research which is freely available for redistribution 